\title{
CONTENTS OF VOLUME 57
}

(Page numbers are at the end of each entry)

\section{ARTICLES AND COMMUNICATION}

Andelic, Patrick Daniel Patrick Moynihan, the 1976 New York senate race, and struggle to define American liberalism

Becker, Tobias Entertaining the empire: theatrical touring companies and amateur dramatics in colonial India

Crook, Malcolm and Dunne, John The first European elections? Voting and imperial state-building under Napoleon, 1802-1813

Forrester, Katrina Citizenship, War, and the origins of international ethics in American political philosophy 1960-1975 . . . . .

Green, Jonathan Allen Friedrich Gentz's translation of Burke's Reflections

Harkins, Robert Elizabethan puritanism and the politics of memory in post-Marian England

Hewitson, Mark On war and peace: German conceptions of conflict, $1792-1815$

Hilliard, Christopher Popular reading and social investigation in Britain, $185^{\text {os- }-1940 s}$

Ingram, Anders The Ottoman siege of Vienna, English ballads, and the exclusion crisis

Irish, Tomás Fractured families: educated elites in Britain and France and the challenge of the Great War

Jones, Emma L. and Pemberton, Neil Ten Rillington Place and the changing politics of abortion in modern Britain

Jones, Rhys Beethoven and the sound of revolution in Vienna, 1792-1814

Koabel, GregYouth, manhood, political authority, and the impeachment of the duke of Buckingham

Laqua, Daniel Pacifism in fin-de-siècle Austria: the politics and limits of peace activism . . . . . . . . . . .

Love, Gary The periodical press and the intellectual culture of Conservatism in interwar Britain

Mahlberg, Gaby Les juges jugez, se justifiants (1663) and Edmund Ludlow's Protestant network in seventeenth-century Switzerland

Murphy, Christopher J. and Lomas, Daniel W. B. Return to Neverland? Freedom of information and the history of British intelligence

Neufeld, Matthew Parliament and some roots of whistle blowing during the Nine Years War

Pettigrew, William A. and Van Cleve, George W. Parting companies: the Glorious Revolution, company power, and imperial mercantilism 
Plassart, Anna Scottish perspectives on war and patriotism in the 1790 s

Polizzotto, Carolyn What really happened at the Whitehall Debates?

A new source

Prott, Volker Tying up the loose ends of national self-determination:

British, French, and American experts in peace planning, 1917-1919

Rex, Richard The religion of Henry VIII

Ritchie, Daniel Abolitionism and evangelicalism: Isaac Nelson, the

Evangelical Alliance, and the transatlantic debate over Christian

fellowship with slaveholders

Ross, Alan S. Pupils' choices and social mobility after the Thirty Years War: a quantitative study

Scriven, Tom Humour, satire, and sexuality in the culture of early Chartism

Sirota, Brent $S$. The occasional conformity controversy, moderation, and

the anglican critique of modernity, $1700-1714$

Tamir, Dan From a fascist's notebook to the principles of rebirth:

the desire for social integration in Hebrew fascism, 1928-1942

Taylor, Michael Conservative political economy and the problem of colonial slavery, 1823-1833

Tomlinson, Jim The political economy of globalization: the genesis of

Dundee's two 'United Fronts' in the 1930 os

Vandrei, Martha A victorian invention? Thomas Thornycroft's 'Boadicea group' and the idea of historical culture in Britain .

Varnava, Andrekos French and British post-war imperial agendas and forging an Armenian homeland after the genocide: the formation of the Légion d'Orient in October 1916.

REVIEW ARTICLES AND HISTORIOGRAPHICAL REVIEWS

Gehring, David Scott From the strange death to the odd afterlife of Lutheran England

Green, Abigail Humanitarianism in nineteenth-century context: religious, gendered, national

Houston, R. A. A latent historiography? The case of psychiatry in Britain, 15 OO-1820

Hutton, Ronald The making of the early modern British fairy tradition

Litvine, Alexis D. The industrious revolution, the industriousness discourse, and the development of modern economies

Plank, Geoffrey Protestantism in a multi-cultural early America .

Shermer, Elizabeth Tandy Who is wagging whom? Power and the new history of American populism

Smyth, James J. Thomas Chalmers, the 'godly commonwealth', and contemporary welfare reform in Britain and the USA 


\section{Central European History}

Published for the Central European History Society

\section{Editor}

Andrew I. Port, Wayne State University, USA

Central European History offers articles, review essays, and book reviews that range widely through the history of Germany, Austria, and other German-speaking regions of Central Europe from the medieval era to the present. All topics and approaches to history are welcome, whether cultural, social, political, diplomatic, intellectual, economic, and military history, as well as historiography and methodology. Contributions that treat new fields, such as post-1945 and post-1989 history, maturing fields such as gender history, and less-represented fields such as medieval history and the history of the Habsburg lands are especially desired.

\section{Membership}

Becoming a member of the Central European History Society is easy! Membership comes with a subscription to the journal Central European History (CEH). Subscribe to the journal and join the group.

Yearly dues for CEH are $\$ 42$ for full members and $\$ 27$ for student members. For an additional $\$ 10$ the member receives online access to all volumes of the journal.

Subscribing to $C E H$ is easy via the $C E H$ website. To get there, follow the link: http://journals.cambridge.org/CEHS

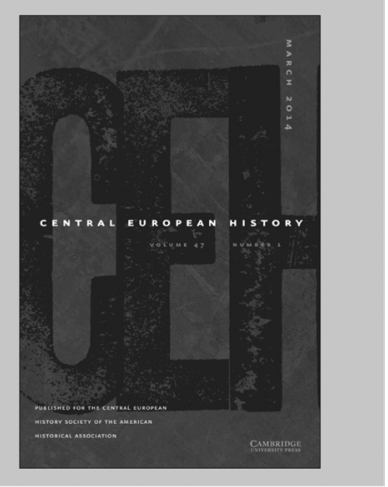

\section{Central European History}

is available online at:

http://journals.cambridge.org/cec

To subscribe contact

Customer Services

\section{in Cambridge:}

Phone +44 (0)1223 326070

$\mathrm{Fax}+44$ (0)1223 325150

Email journals@cambridge.org

\section{in New York:}

Phone +1 (845) 3537500

$\mathrm{Fax}+1$ (845) 3534141

Email

subscriptions_newyork@cambridge.org

\section{Free email alerts}

Keep up-to-date with new material - sign up at

journals.cambridge.org/register 


\section{Royal Historical} Society

\section{Publications}

Published on behalf of The Royal Historical Society

\section{RHS Literary Directors}

lan W. Archer, University of Oxford, UK

Emma Griffin, Univeristy of East Anglia, UK

The Royal Historical Society has published the highest quality scholarship in history for over 150 years. A subscription includes a substantial annual volume of the Society's Transactions, which presents wide-ranging reports from the front lines of historical research by both senior and younger scholars, and two volumes from the Camden Fifth Series, which makes available to a wider audience valuable primary sources that have hitherto been available only in manuscript form.
PUBLICATIONS OF THE

ROYAL HISTORICAL SOCIETY

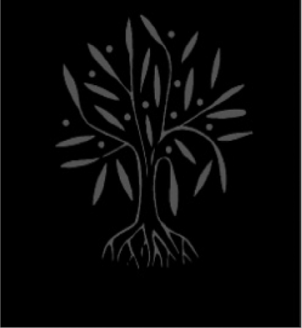

Royal Historical Society Publications

is available online at:

http://journals.cambridge.org/rhs

To subscribe contact

Customer Services

\section{Americas:}

Phone +1 (845) 3537500

Fax +1 (845) 3534141

Email

subscriptions_newyork@cambridge.org

\section{Rest of world:}

Phone +44 (0)1223 326070

$\mathrm{Fax}+44(0) 1223325150$

Email journals@cambridge.org

Free email alerts

Keep up-to-date with new material - sign up at

journals.cambridge.org/register 


\section{Contemporary \\ European History}

\section{Editors}

Dejan Djokić, Goldsmiths, University of London, UK

N. Piers Ludlow, London School of Economics and Political Science, UK Josie McLellan, University of Bristol, UK

Jessica Reinisch, Birkbeck, University of London, UK

Tara Zahra, Birkbeck, University of Chicago, USA

Contemporary European History covers the history of Eastern and Western Europe, including the United Kingdom, from 1918 to the present. By combining a wide geographical compass with a relatively short time span, the journal achieves both range and depth in its coverage. It is open to all forms of historical inquiry - including cultural, economic, international, political and social approaches - and welcomes comparative and transnational analysis. One issue per year explores a broad theme under the guidance of a guest editor. The journal regularly features contributions from scholars outside the Anglophone community and acts as a channel of communication between European historians throughout the continent and beyond it.

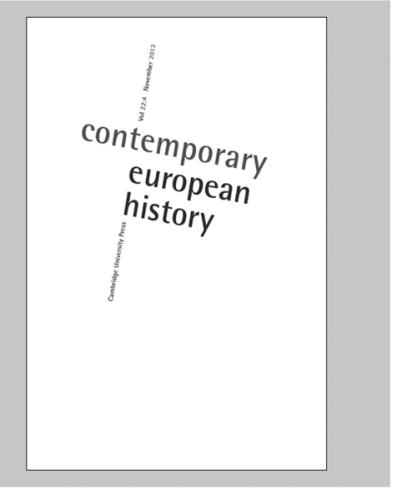

Contemporary European History is available online at: http://journals.cambridge.org/ceh

To subscribe contact Customer Services

\section{Americas:}

Phone +1 (845) 3537500

Fax +1 (845) 3534141

Email

subscriptions_newyork@cambridge.org

\section{Rest of world:}

Phone +44 (0)1223 326070

$\mathrm{Fax}+44$ (0)1223 325150

Email journals@cambridge.org

\section{Free email alerts}

Keep up-to-date with new material - sign up at

journals.cambridge.org/register 
Access a free trial for the new online bibliography from the Financial History Review

\section{Editor}

Stefano Battilossi - Universidad Carlos III Madrid, Spain

Associate Editor

David Weiman - Columbia University, USA

The Financial History Review (FHR) is pleased to announce the arrival of an online bibliography. Access to this database is an automatic benefit available to all online subscribers to the $\boldsymbol{F H}$. However, you can access the bibliography today for a 15 day free trial by following the link at the bottom of this page.

The FHR Bibliography is an authoritative guide to works published in the field of Financial History since 1990. This consolidated version of the printed bibliography brings together every record since 2000 in a searchable database, producing a rich interactive resource, crucial to the research of scholars interested in the study of financial issues through time.

To access the FHR Bibliography, simply go to the following web-page, and fill-in the short form, using the offer code FHRAD:

http://fhrbibliography.cambridge.org

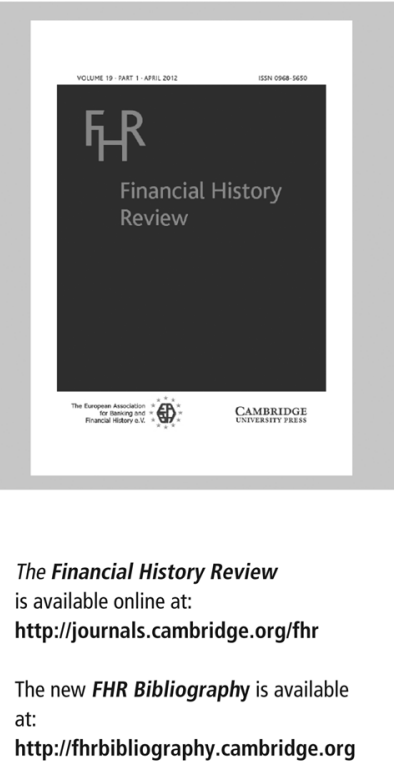

Useful Links:

Recommend the Financial History Review to your librarian at:

http://journals.cambridge.org/

recommend_fhr

To register for content alerts, go to: http://journals.cambridge.org/fhr-alerts 


\section{Plainsong \& Medieval Music}

Published in association with the

Plainsong and Medieval Music Society and Cantus Planus

\section{Editors}

James Borders, University of Michigan, USA

Christian Thomas Leitmeir, Bangor University, UK

Plainsong \& Medieval Music is published twice a year in association with the Plainsong and Medieval Music Society and Cantus Planus, study group of the International Musicological Society. It covers the entire spectrum of medieval music: Eastern and Western chant, secular lyric, music theory, palaeography, performance practice, and medieval polyphony, both sacred and secular, as well as the history of musical institutions. The chronological scope of the journal extends from late antiquity to the early Renaissance and to the present day in the case of chant. In addition to articles embodying original research, the journal publishes book reviews, an annual bibliography of chant research and an annual discography of chant recordings.

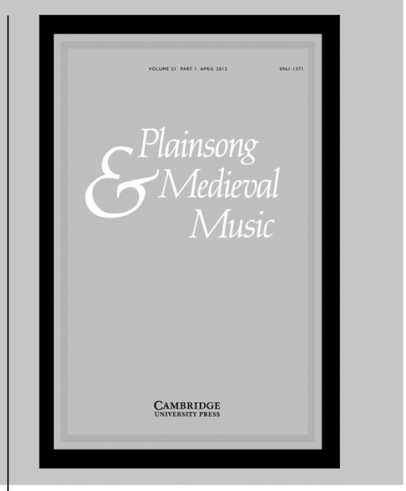

Plainsong \& Medieval Music is available online at: http://journals.cambridge.org/pmm

To subscribe contact Customer Services

\section{in Cambridge:}

Phone +44(0)1223 326070

Fax $+44(0) 1223325150$

Email journals@cambridge.org

\section{in New York:}

Phone +1 (845) 3537500

Fax +1 (845) 3534141

Email

subscriptions_newyork@cambridge.org

\section{Free email alerts}

Keep up-to-date with new material - sign up at

journals.cambridge.org/register 


\title{
CAMBRIDGE
}

\section{GREAT MINDS COME FROM GREAT BOOKS}

\section{The History Manifesto}

\author{
Jo Guldi and David Armitage
}

\$45.00 / f30.00: Hardback: 978-1-107-07634-1: 176 pp.

\$19.99 / f12.99: Paperback: 978-1-107-43243-7
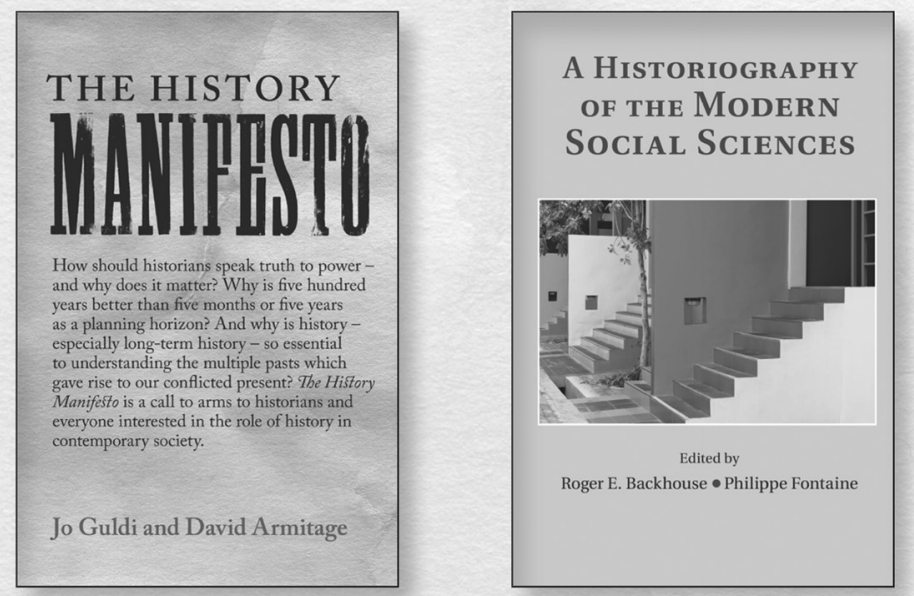

\section{A Historiography of the Modern Social Sciences}

Edited by Roger E. Backhouse and Philippe Fontaine \$95.00 / f60.00: Hardback: 978-1-107-03772-4: 252 pp. 
Founded in 1958, The Historical fournal publishes on all aspects of history since 1500, providing a forum for younger scholars making a distinguished debut as well as publishing the work of historians with an international reputation. The journal publishes original research in full-length articles and shorter communications and major surveys of the field in historiographical reviews and review articles. Contributions are aimed both at specialists and non-specialists.

Submissions should be made online at http://mc.manuscriptcentral.com/hj.

Please contact the part-time office at hj@hist.cam.ac.uk if you have any questions about the procedure, or wish to make a submission by another means.

Detailed instructions concerning submission and style, which must be consulted before a manuscript is submitted, are available at

\section{http://journals.cambridge.org/images/fileUpload/images/HIS_ifc.pdf}

We aim to make a decision on submissions within three months and to publish the final version of an accepted article within six months of receipt.

Books for review should be sent to: The Editors, The Historical fournal, Faculty of History, West Road, Cambridge CB3 9EF.

\section{GOPYING}

This journal is registered with the Copyright Clearance Center, 222 Rosewood Drive, Danvers, MA oig23, USA. Organizations in the USA who are also registered with the C.C.C. may therefore copy material (beyond the limits permitted by sections I07 and Io8 of US Copyright law) subject to payment to C.C.C. of the per copy fee of \$12.oo. This consent does not extend to multiple copying for promotional or commercial purposes. Code 0or8-246x/I4 \$12.00. ISI Tear Sheet Service, 350i Market Street, Philadelphia, PA I9I04, USA, is authorized to supply single copies of separate articles for private use only. Organizations authorized by the Copyright Licensing Agency may also copy material subject to the usual conditions. For all other use, permission should be sought from Cambridge University Press.

\section{(C) Cambridge University Press 2014}

\section{CAMBRIDGE UNIVERSITY PRESS}

Journals Fulfillment Department, UPH, Shaftesbury Road, Cambridge CB2 8BS, UK. 32 Avenue of the Americas, New York, NY ioor3-2473, USA

477 Williamstown Road, Port Melbourne, VIC 3207, Australia Ruiz de Alarcón I3, 28014 Madrid, Spain

Dock House, The Waterfront, Cape Town 8oor, South Africa

Printed in the UK by Bell \& Bain Limited 


\section{THE HISTORICAL JOURNAL}

\section{CONTENTS}

\section{ARTICLES}

ROBERT HARKINS Elizabethan puritanism and the politics of memory in post-Marian England

KATE DAVISON Occasional politeness and gentlemen's laughter in $18^{\text {th }} \mathrm{C}$ England

RHYS JONES Beethoven and the sound of revolution in Vienna, 1792-1814

MiCHAEL TAYLOR Conservative political economy and the problem of colonial slavery, 1823-1833

ANDREKOS VARNAVA French and British post-war imperial agendas and forging an Armenian homeland after the genocide: the formation of the Légion d'Orient in October 1916

GARY LOVE The periodical press and the intellectual culture of Conservatism in interwar Britain

DAN TAMIR From a fascist's notebook to the principles of rebirth: the desire for social integration in Hebrew fascism, 1928-1942

EMma L. Jones And NeIL PEMBERTON Ten Rillington Place and the changing politics of abortion in modern Britain

PATRICK ANDELIC Daniel Patrick Moynihan, the 1976 New York Senate race, and the struggle to define American liberalism

Historiographical Reviews

RONALD HUTTON The making of the early modern British fairy tradition

ABIGAIL GREEN Humanitarianism in nineteenth-century context: religious, gendered, national

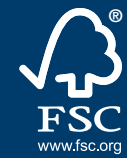

CAMBRIDGE UNIVERSITY PRESS 